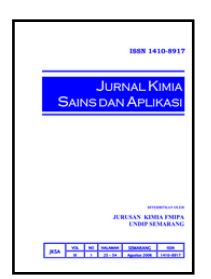

\title{
Penentuan Waktu Optimum Reaksi Reduksi Metil Laurat Minyak Kelapa Menggunakan $\mathrm{NaBH}_{4}$
}

\author{
Hanna Niela Diana ${ }^{\mathrm{a}}$, Ngadiwiyana ${ }^{\mathrm{b}}$, Arnelli $^{\mathrm{*}}$ \\ a Physical Laboratory, Chemistry Department, Faculty of Sciences and Mathematics, Diponegoro University, Jalan Prof. Soedarto, \\ Tembalang, Semarang \\ b Organic Chemistry Laboratory, Chemistry Department, Faculty of Sciences and Matematics, Diponegoro University, Jalan Prof. \\ Soedarto, Tembalang, Semarang 50275, Telepon (024) 7474754 \\ * Corresponding author: arnelli@live.undip.ac.id
}

Article Info

Keywords:

Surfactant sodium lauryl sulfate, transesterification, lauryl alcohol

\section{Abstract}

The sodium lauryl sulfate surfactant can be synthesized from methyl laurate which can be isolated from the coconut oil of the VCO type. In this study, VCO was transesterified with methanol to produce methyl esters using $\mathrm{NaOH}$ as a catalyst. Methyl laurate was separated according to melting point difference. The isolated methyl laurate was reduced to produce lauryl alcohol with $\mathrm{NaBH}_{4}$ as a reducing agent. This study aims were to produce a reduction product and to determine the optimum time of reduction reaction using $\mathrm{NaBH}_{4}$ reducing agent. The variables observed were reduction reaction time $(3,4$, 5 , and 6 hours). In this study, the optimum time was obtained at 4 hours reaction time with the product weight of $0.7044 \mathrm{~g}$ and the degree of reduction of $98 \%$.

\section{Abstrak}

Surfaktan natrium lauril sulfat dapat disintesis dari metil laurat yang dapat diisolasi dari minyak kelapa jenis VCO. Pada penelitian ini, VCO ditransesterifikasi dengan metanol untuk menghasilkan metil ester dengan menggunakan $\mathrm{NaOH}$ sebagai katalis. Metil laurat dipisahkan berdasarkan perbedaan titik leleh. Metil laurat yang telah diisolasi direduksi untuk menghasilkan lauril alkohol dengan $\mathrm{NaBH}_{4}$ sebagai agen pereduksi. Penelitian ini bertujuan untuk menghasilkan produk reduksi dan menentukan waktu optimum reaksi reduksi menggunakan agen pereduksi $\mathrm{NaBH}_{4}$. Variabel yang diamati adalah waktu reaksi reduksi $(3,4,5$, dan 6 jam). Pada penelitian ini, waktu optimum diperoleh pada waktu reaksi 4 jam dengan berat produk $0,7044 \mathrm{~g}$ dan derajat reduksi sebesar $98 \%$.

\section{Pendahuluan}

Kebutuhan masyarakat Indonesia akan produk pembersih, seperti sabun, sampo, pasta gigi, dan pencuci muka semakin meningkat dengan bertambahnya jumlah penduduk di Indonesia. Bahan utama pembuatan produk pembersih tersebut adalah surfaktan yang berfungsi sebagai pembersih untuk mengikat kotoran. Surfaktan dibedakan berdasarkan bahan baku pembuatnya, yaitu surfaktan petrokimia dan surfaktan oleokimia. Surfaktan petrokimia adalah surfaktan yang berasal dari minyak bumi, sedangkan surfaktan oleokimia adalah surfaktan yang berasal dari minyak nabati. Jenis surfaktan berdasarkan muatannya terdiri atas surfaktan anionik, kationik, dan non ionik. Surfaktan anionik adalah surfaktan yang mempunyai gugus hidrofil negatif, sedangkan surfaktan kationik adalah surfaktan yang mempunyai gugus hidrofil positif.

Uysal dan Buyuktas [1] menyatakan bahwa reduksi karbonil sangat dipengaruhi oleh agen pereduksi. Agen pereduksi yang biasa digunakan adalah $\mathrm{NaBH}_{4}$ karena $\mathrm{NaBH}_{4}$ merupakan agen pereduksi yang aman, murah, dan dapat digunakan pada kondisi apapun. Sistem $\mathrm{NaBH}_{4}-\mathrm{meOH}$ dilakukan da Costa dkk. [2] untuk mereduksi ester dengan kondisi reaksi dilakukan pada 
suhu $70{ }^{\circ} \mathrm{C}$ dan waktu reaksi selama 1 jam yang menghasilkan rendemen sebesar $63-100 \%$, sedangkan Saeed dan Ashraf [3] melakukan reduksi pada kondisi suhu reaksi $650 \mathrm{C}$ dengan waktu reaksi antara $2-5$ jam yang menghasilkan rendemen $70-92 \%$. Banyaknya produk yang dihasilkan dari reaksi reduksi dipengaruhi oleh lamanya reaksi berlangsung karena dari mekanisme reaksinya, reaksi reduksi dengan agen pereduksi $\mathrm{NaBH}_{4}$ menghasilkan hasil samping berupa ion metoksida. Ion metoksida bersifat sebagai kompetitor terhadap reaktan karena ion tersebut akan bereaksi dengan produk membentuk eter sehingga produk yang dihasilkan berkurang. Untuk itu, perlu dilakukan penelitian yang mengamati pada waktu tertentu dihasilkan produk paling maksimum sehingga dapat ditentukan waktu optimumnya.

\section{Metode Penelitian}

Minyak kelapa jenis VCO ditentukan bilangan asamnya dengan cara mentitrasi dengan $\mathrm{NaOH}$, kemudian dilakukan penurunan bilangan asam. Preparasi katalis yang digunakan untuk transesterifikasi dengan cara melarutkan dalam metanol $96 \%$ untuk membentuk natrium metoksida. Katalis yang sudah dipreparasi kemudian dicampur ke dalam minyak di dalam labu alas bulat. Reaksi dilakukan pada suhu $70{ }^{\circ} \mathrm{C}$ selama 90 menit.

Metil ester hasil transesterifikasi yang telah dipisahkan dari gliserol dicuci dengan aquades sampai netral, kemudian $\mathrm{Na}_{2} \mathrm{SO}_{4}$ anhidrat ditambahkan ke dalam metil ester agar air yang masih terkandung dapat diserap. $\mathrm{Na}_{2} \mathrm{SO}_{4}$ kemudian dipisahkan dari metil ester dengan cara penyaringan. Metil ester kemudian dibekukan selama 8-10 jam. Metil ester yang telah membeku seluruhnya diletakkan pada suhu $5{ }^{\circ} \mathrm{C}$ (titik leleh metil laurat) selama 1,5 jam. Metil ester yang meleleh kemudian disaring dan dianalisis dengan menggunakan metode GC-MS.

Metil laurat kemudian direduksi dengan agen pereduksi $\mathrm{NaBH}_{4}$. metil laurat hasil isolasi dilarutkan dalam THF, kemudian direfluks sampai suhu $60{ }^{\circ} \mathrm{C}$ selama 15 menit. $\mathrm{NaBH}_{4}$ dicampur dengan metil laurat dalam THF dan direfluks pada suhu $65^{\circ} \mathrm{C}$ dengan variasi waktu 3, 4, 5, dan 6 jam. Hasil reduksi kemudian dinetralkan dengan $\mathrm{HCl}$ kemudian dipisahkan. Bagian organik dipisahkan dan bagian non organik diekstraksi dengan menggunakan etil asetat. Hasilnya didiamkan sampai terbentuk kristal kemudian disaring dan kristal dianalisis menggunakan spektrofotometer FTIR.

\section{Hasil Dan Pembahasan}

Tabel 1 menunjukkan bahwa pada waktu reaksi selama 5 jam terjadi penurunan berat produk dan rendemen. Hal ini disebabkan karena pada waktu reaksi selama 5 jam dihasilkan produk samping berupa eter. Produk samping ini terbentuk karena adanya ion metoksida yang bereaksi dengan alkohol produk sehingga produk alkohol yang diinginkan berkurang. Secara kuantitatif, produk paling maksimum terjadi pada waktu rekasi selama 4 jam.
Tabel 1. Hasil reduksi metil laurat minyak kelapa menggunakan $\mathrm{NaBH}_{4}$

\begin{tabular}{cccc}
\hline $\begin{array}{c}\text { Waktu } \\
\text { Refluks } \\
\text { (Jam) }\end{array}$ & $\begin{array}{c}\text { Berat } \\
\text { Produk } \\
\text { (gram) }\end{array}$ & $\begin{array}{c}\text { Rendemen } \\
(\%)\end{array}$ & $\begin{array}{c}\text { Derajat } \\
\text { Reduksi } \\
(\%)\end{array}$ \\
\hline 3 & 0,6002 & 10,7 & 88 \\
4 & 0,7044 & 12,6 & 98 \\
5 & 0,4101 & 7,37 & 69 \\
6 & 0,4737 & 8,51 & 85 \\
\hline
\end{tabular}

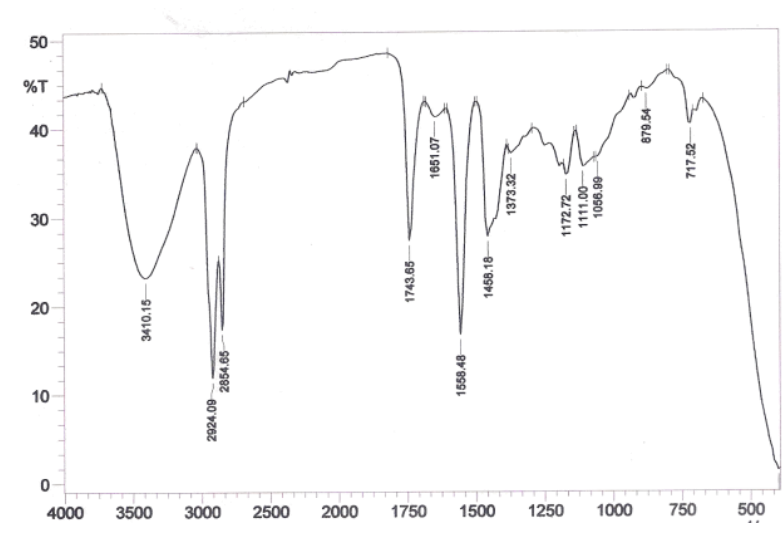

Gambar 1. waktu reaksi 3 jam

Dari analisis FTIR menunjukkan bahwa derajat reduksi pada waktu reaksi 3 jam sebesar $88 \%$ dengan absorbansi $\mathrm{C}=\mathrm{O}$ sebesar 0,56 dan absorbansi $\mathrm{OH}$ sebesar 0,63 yang terlihat pada gambar 1 .

Derajat reduksi pada waktu reaksi 4 jam sebesar 98\% dengan absorbansi $\mathrm{C}=\mathrm{O}$ sebesar 0,52 dan absorbansi $\mathrm{OH}$ sebesar 0,53 yang terlihat pada gambar 2 .

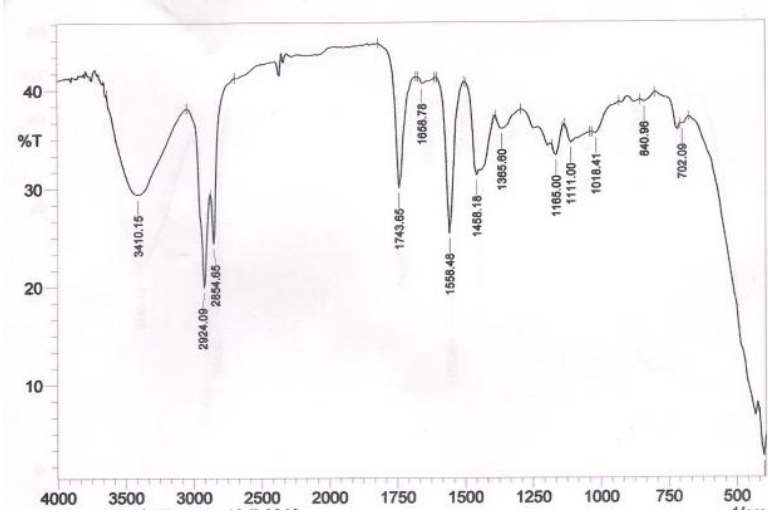

Gambar 2. waktu reaksi 4 jam

Derajat reduksi pada waktu reaksi 5 jam sebesar 69\%dengan absorbansi $\mathrm{C}=\mathrm{O}$ sebesar 0,18 danabsorbansi $\mathrm{OH}$ sebesar 0,26 yang terlihat pada gambar 3 .

Derajat reduksi pada waktu reaksi 6 jam sebesar $85 \%$ dengan absorbansi $\mathrm{C}=\mathrm{O}$ sebesar 0,64 dan absorbansi $\mathrm{OH}$ sebesar 0,75 yang terlihat pada gambar 4 . 


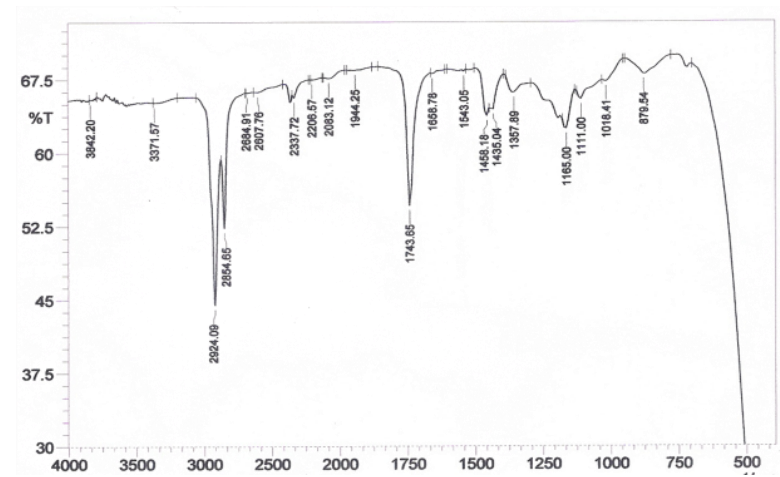

Gambar 3. waktu reaksi 5 jam

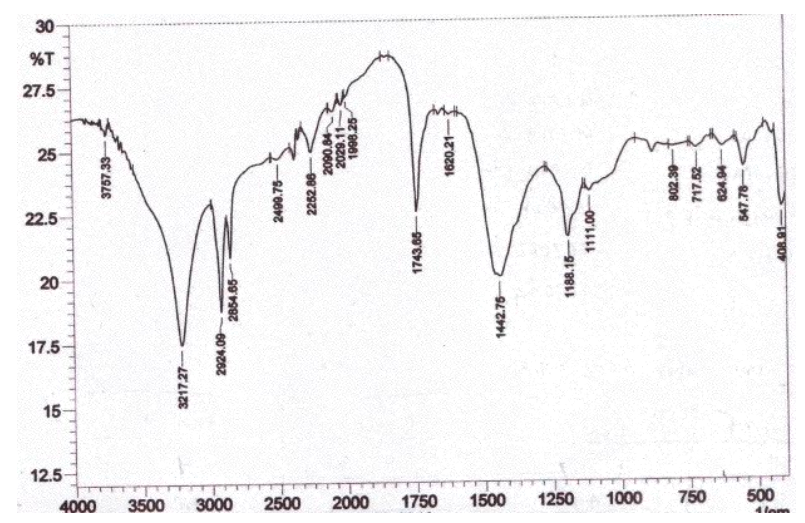

Gambar 4. Waktu reaksi 6 jam

Dari nilai derajat reduksi pada masing-masing waktu reaksi, derajat reduksi paling besar yaitu pada waktu reaksi selama 4 jam. Derajat reduksi menunjukkan banyaknya gugus ester yang tereduksi, semakin besar nilai derajat reduksi maka semakin banyak gugus ester yang telah tersubstitusi tereduksi. Hal ini dapat disimpulkan bahwa waktu optimum reaksi reduksi metil laurat minyak kelapa menggunakan $\mathrm{NaBH}_{4}$ adalah 4 jam dengan berat produk $0,7044 \mathrm{~g}$ dan derajat reduksi $98 \%$.

\section{Kesimpulan}

Pada reaksi reduksi metil laurat diperoleh produk berupa padatan putih seperti lilin dengan titik leleh 27,6 ${ }^{\circ} \mathrm{C}$ dan hasil diperkirakan lauril alkohol yang belum murni. Reaksi reduksi metil laurat menggunakan $\mathrm{NaBH}_{4}$ memiliki waktu optimum pada waktu reaksi selama 4 jam dengan berat 0,7044 gram dan derajat reduksi sebesar $98 \%$.

\section{Daftar Pustaka}

[1] Burcu Uysal, Birsen Buyuktas, Kinetics of catalytic Meerwein-Ponndorf-Verley reduction of aldehydes and ketones using boron triethoxide, Chemical Papers, 64, 1, (2010) 123-126 http://dx.doi.org/10.2478/s11696-009-0098-3

[2] Jorge CS da Costa, Karla C Pais, Elisa L Fernandes, Pedro SM de Oliveira, Jorge S Mendonça, Marcus VN de Souza, Mônica A Peralta, Thatyana RA Vasconcelos, Simple reduction of ethyl, isopropyl and benzyl aromatic esters to alcohols using sodium borohydride-methanol system, Arkivoc, 1, (2006) 128-133
[3] Aamer Saeed, Zaman Ashraf, Sodium borohydride reduction of aromatic carboxylic acids via methyl esters, Journal of chemical sciences, 118, 5, (2006) 419-423 https://dx.doi.org/10.1007/BF02711452 